\title{
Family Ownership and Dividend Policy: Empirical Evidence from Malaysia
}

\author{
Vasanthan Subramaniam ${ }^{1}$ \\ ${ }^{1}$ Multimedia University, Malaysia \\ Correspondence: Vasanthan Subramaniam, Multimedia University, Malaysia. E-mail: vasuuum@gmail.com
}

Received: February 15, 2018

Accepted: March 10, 2018

Online Published: April 18, 2018

doi:10.5539/ijbm.v13n5p112

URL: https://doi.org/10.5539/ijbm.v13n5p112

\begin{abstract}
The objective of this study is to investigate the relationship between family ownership and dividend in Malaysian publicly listed firms. Malaysia served as a distinctive country to conduct this research as the corporate structure is largely characterised as family owned and the corporate firms are highly involved in high and stable dividends. The study uses data from 712 firms over the period of five (5) years from the year 2010 to 2014. Adjusted ordinary least square (OLS) regression methods are employed to analyse the data used in the study. Based on the results, family ownership is seen to have a significant positive relationship with dividends in Malaysia, especially in family firms. The finding has supported the reputational view of dividend, mitigation of agency conflict and dividends as the source of income for the family shareholders. However, the expropriation motive of the controlling family shareholders can still be relevant as high dividends were certainly paid to themselves as they are the majority shareholders in the firm. The contribution of the study lies in the behaviour of the controlling family shareholders in both family and non-family firms in Malaysia. The actual motives of them in relation to the enhancement of the shareholders' wealth can be revealed through the findings of this study.
\end{abstract}

Keywords: family ownership, dividend, agency conflict, Malaysia

\section{Introduction}

Family firms contribute extensively to the development of the economy of the emerging countries especially Malaysia (Ghee et al., 2015; The Economists, 2015). Most of the publicly listed firms in Malaysia starts from the family business. Past research has shown that family firms have controlled majority portion of the GDP in Malaysia. The number of family firms will continue to grow as the Malaysian economy progress towards high-income economy in the future. Presently, there are many well-known public firms in Malaysia such as YTL, Genting, IOI, GAMUDA and much more. Family businesses usually adopt strong family culture into the business and all the decision pertaining to the financial policies in the firm are also strongly related to the family culture (The Economists, 2015).

The prominent feature of family firms is the concentrated and controlling pattern of ownership in the firm (Carney \& Child, 2013; Claessens et al., 2001). Family firms are generally controlled by the founders and their related family members. They usually hold a few block-shares that cumulatively control the firm. Much of past research has documented their evidence on the concentrated pattern of ownership of firms in South East Asian Countries especially in Malaysia (Carney \& Child, 2013; La Porta et al., 2000). For instance, La Porta et al. (1999) found that most of the large firms in South East Asian countries are mainly controlled by the family shareholders. Similar evidence was also found by Carney and Child (2013) in East Asian perspective. This study has showed that the concentrated pattern of ownership of the controlling family shareholders for the year 1996 and 2008 are almost similar. This pattern of ownership has not significantly changed over the years (Carney \& Child, 2013).

In contrast to the pattern of ownership in developing countries, most of the public firms in developed countries (like in the US and the UK) are widely controlled by the family shareholders (Rajan \& Zingales, 2003; Ramli, 2010). They usually entrust their control to the managers to manage their firm. This can results in the separation of ownership and control rights of share, which eventually creates difficulties for the external shareholders to monitor the behaviour of the manager (Morck \& Yeung, 2003). The unmonitored manager will manage firm in favour of their own interest which may results them to commit fraud and make investment that generates 
sub-optimal returns. This separation of ownership and control rights in public firms eventually leads to agency conflict between the external shareholders and managers (Type 1) agency conflict (Jensen \& Meckling, 1976). The creation of this agency conflict is also due to the interest of the principals (shareholders) are not aligned with the interest of the managers in the firm.

However, in the firms with concentrated and controlling pattern of ownership, firm's management is usually pre-dominantly controlled by the controlling family shareholders (Gonzalez et al., 2014). The controlling shareholders usually closely monitor the behaviour of the managers in the firm, which reduces the separation between ownership and control rights of shares in the firm. Moreover, the controlling family shareholders usually appoint their own family members to hold position in the management team (Gonzalez et al. 2014). Therefore, the prevalence of this controlling power of the family shareholder can reduce Type 1 agency conflict generated by the self-centred managers. However, excess control rights of the controlling family shareholders may generate another type of agency conflict between the controlling shareholders and minority shareholders (Type 2) agency conflict. This can be the worst type of agency conflict as the controlling shareholders may misuse their substantial control to act in favour of their self-interest (family interest) rather than work to enhance the overall shareholders' wealth (Young et al., 2008).

Since the controlling power can generate conflict of interest between the shareholders in the firm, their decision on the firm's financial policy may also be in the conflicting position. One of the most important and frequent financial decision in the firm is decision on its dividend policy. The conflict of interest of the controlling family shareholders may indirectly affects the dividend policy decision, as argued by Jensen (1986) and La Porta et al. (2000). Nevertheless, the controlling power of the family shareholders can also provide an alternate governance mechanism in the firm (Mishra et al., 2001). Family shareholders may manage their firms efficiently with the strong business value to enhance the overall shareholders' wealth. As a results of this, family firms could perform better compared to the other types of firm. The family traits are not necessarily harms the shareholders, but instead it could provide a competitive advantage that can improve firm performance in the future. Firms that are perform better can also pay high dividends to its shareholders.

The study is focussed on the Malaysian corporate environment as the Malaysian firms are highly owned by the family shareholders (Carney \& Child, 2013). These firms are also classified as one of the largest dividend payers in Asia (Yap, 2012) and stable dividends were paid across multiple years (Pandey, 2013). There are much research on the subjects of ownership structure and the dividend policy that have been conducted in developed and large economies. However, no studies have been conducted in Malaysia by using data of all firms listed on Bursa Malaysia. More accurate contribution can be highlighted by using all data of firms rather than a selected sample firms. Further, as the firms in developing countries are having unique characteristics of corporate culture, it may provide a different and meaningful contribution to the research of ownership structure and dividend policy.

Additionally, there are some studies were conducted in Indonesia, China and Columbia which concluded that the controlling family shareholders were involved in expropriation activities through payment of low dividends (Mulyani et al., 2016; Lv et al., 2012; Gonzalez et al., 2014). However, the controlling family shareholders in Malaysia may not necessarily involve in the expropriation activities as found in the above studies. The shareholders' protection in Malaysia (Faccio et al., 2001) may provide a platform for the minority shareholders to exert pressure on the management of the Malaysian firms to pay high dividends. Thus, the theoretical contribution is that the controlling family shareholders may not necessarily create agency conflict (Type 2 ) in the firm. Further, the 'outcome model' discussed by La Porta et al. (2000), may also be relevant in Malaysia. Based on this 'outcome model', dividends were paid due to the strong legal protection of the shareholders. Hence, Malaysian public firms may pay high dividends to satisfy the needs of the minorities who can anticipate potential expropriation activities with the presence of the controlling ownership.

The study, therefore, raised the following research question: What is the relationship between family ownership and dividend policy in Malaysia? The following sections of the study are structured as follows: Section 2 is on the review of literature related to family ownership, agency conflict and dividend. Hypothesis formulation is also discussed in Section 2. Section 3 provides the model, data description, measurement of variables and the research methodology. The results are presented in Section 4 and discussed in Section 5 while the final section, Section 6 concludes the study.

\section{Review of Literature}

\subsection{Family Ownership, Agency Conflict and Dividend}

Agency theory is the underlying theory that discussed agency relationship in the firm controlled by the 
controlling family shareholders. The core concept of the agency theory is on the conflict of interest that arises from risk sharing by the principals (external shareholders) and the agents (internal shareholders) in the firm (Frank \& Meyers, 1933; Mitnick, 1973; 2015). Principals are the shareholders of the firm while the agents are the management team entrusted by the principals to manage the firm. Conflict arises as these parties were having a different risk tolerance that aims for different goals and objectives on the business transactions. Therefore, agency theory is important as it implies the agency relationship between the shareholders and the agents in the firm.

Agency theory has been used by many scholars in finance literature such as Jensen and Meckling (1976), Eisenhardt (1989) and Mitnick (1973). In a nutshell, agency theory is about the principal-agent relationship which is formed as a basis of the corporate governance model. The pivotal justification of the modern enterprise is the conflicting interest between the insiders and outsiders of the firm (Jensen \& Meckling, 1976). The conflicting interest is also the consequences of the separation of ownership and control rights of the shareholders in the firm. Basically, there are two natures of conflict that arises in an agency relationship (social interaction) (Eisenhardt, 1989; Mitnick, 1973, 2015), namely is when the desire of the principal and agent differs and when the principal could not monitor the entrusted agent in the firm. As the principal and agent's desire differ, their goals and objectives may also differ substantially (Jensen \& Meckling, 1976). The principals' intention is to raise their shareholdings value while the agent's intention is to raise the compensation. The situation becomes even worst with the lack of transparency on the activities of the agent in the firm. Both of these problems will lead to the vulnerability of the agency relationship in the firm.

Generally, as discussed earlier, two types of agency conflict arise in the firm; the first is Type 1 agency conflict between the managers and shareholders, and the second is Type 2 agency conflict between the controlling shareholders and minority shareholders (Jensen \& Meckling, 1976; Eisenhardt, 1989). A firm controlled by family shareholders would have severe Type 2 agency conflict compared to Type 1 agency conflict. Family shareholders are the most prominent type of shareholders in emerging countries, especially in Malaysia (Carney \& Child, 2013; Claessens et al., 2001). They may act in several ways to obtain substantial benefits from exploiting their control and power in the firm (Fama \& Jensen, 1983). The action of the controlling shareholders may be detrimental to the minority shareholders. The overall wealth of the shareholders is not being taken care of by the controlling shareholders. This problem arises as the interests of the controlling shareholders and the minority shareholders are not aligned with each other (Fama \& Jensen, 1983). Conversely, family firms can also contribute positively to the improvement of the agency relationship by making decisions more quickly and fairly which would be of great service to the minority shareholders (Mishra et al., 2001). This could guarantee long-term stability, commitment to service the shareholders, and love for the business (James, 1999). In fact, according to La Porta et al. (1999), many large firms would like to adopt the family traits in order to enhance the competitive advantage of the business and improve their firm performance in the long-run.

Agency cost model has been widely used in the finance literature especially in those discussing dividend policy (Jensen, 1986; La Porta et al., 2000). Miller and Modigliani's (1958) seminal papers which discussed the irrelevance of dividend policy led to the interest in the issue of corporate dividend policy in finance literature. No final conclusion with regards to the dividend policy of the firm has been achieved. Scholars have modelled a number of hypotheses that could explain the purpose of the dividend policy; however, the issue still remains a puzzle. Some hypotheses on dividend could be viewed from the agency cost perceptive. The dividend could be the result or solution to the agency conflicts (Easterbrooks, 1984). Dividends could bridge the gap in the agency relationship between managers and shareholders and that of the controlling shareholders and the minority shareholders.

According to Easterbrooks (1984), dividends can reduce agency problem in the firm. Firms that have paid dividends would have lack of retained earnings that can be used to finance future projects. Hence, these firms need to use the external capital to finance those projects. The use of external capital is more effective as it could discipline the managers (Easterbrook, 1984). Management scrutiny could be enhanced and this could limit managers from extracting private benefits from the firm. Dividend reduces agency cost by improving the monitoring behaviour and risk-taking incentives of the managers (Easterbrook, 1984; Jensen, 1986). Thus, dividends can be classified as a cost-effective substitute for the monitoring role of the shareholders. Moreover, as argued by Jensen (1986), the dividend could also reduce the availability of cash flow in the hand of managers, thus it can reduce agency cost on the free cash flow. Managers may misuse the mandate and power given to them by using cash to invest in their preferred projects (pet-projects) rather than paying dividends to the shareholders (Jensen \& Meckling, 1976; Afza \& Mirza, 2010). The investment in the preferred projects may be the result of the motive to expropriate or tunnel resources from the firm. The misuse of free cash flow could be diminished by 
transferring out the cash to shareholders in the form of dividends (Mancinelli \& Ozkan, 2006). Hence, dividends could diminish this agency conflict by limiting resources at the managers' discretion (Easterbrook, 1984; Jensen, 1986; Mancinelli \& Ozkan, 2006). Additionally, according to Jensen (1986), the commitment to pay high dividends curbs the managers' behaviour of engaging in over-investment. Therefore, investment and dividend policies are interrelated with each other, which is against the arguments propounded by Miller and Modigliani (1958).

Nevertheless, the controlling shareholders may engage in rent extraction and enjoy private benefits of control from high dividends for themselves (Gugler \& Yurtoglu, 2003; Pindado et al., 2012). Payment of high dividends to themselves could actually transfer the firm's cash flow to the controlling shareholders. The extraction of the resources is against the interest of the minority shareholders. This behaviour is usually profound in firms where corporate pyramid structure exists as discovered by Faccio et al. (2001) in their study of firms in Western Europe and East Asian countries. Controlling shareholders basically try to mask their expropriation behaviour through high dividend pay-outs, where the minority and non-family shareholders could signal credibility of behaviour from the high dividends (Pindado et al., 2012). This scenario is far better than the environment where the dividend is rarely being paid. In this scenario, the dividend could be the result of agency conflict (dividend creates agency conflict) consistent with the argument posed by Easterbrooks (1984). It usually happens in the countries with strong legal protection to the minorities.

The interrelations between agency conflict and dividends are supported by Rozeff (1982). Rozeff (1982) argued that the optimal dividend policy can minimize the transaction costs and agency cost of the firm. Holder et al. (1998) and Saxena (1999) have supported these arguments based on the study using the US firms. While the free cash flow hypothesis provided by Jensen (1986) has been supported by Lang and Litzenberger (1989) who found that dividends could mitigate agency cost related to over-investment. La Porta et al. (2000) found that high dividends are usually paid in the country with strong shareholders' protection based on the 'outcome' and 'substitution' models. The 'outcome' model explained that dividend is the outcome of strong corporate governance practice (strong legal protection) in the country. Dividends could reduce the expropriation initiative in the firm. However, according to 'substitution' model, high dividends actually substitutes the compliance of corporate mechanism in a country that is poorly governed (weak legal protection). In this case, high dividends usually paid to establish a reputation among the shareholders to raise capital in the future (Benjamin et al., 2016; Schmid et al., 2010).

\subsection{The Relationship between Family Ownership and Dividend}

In order to answer the Research Question (RQ) presented in introduction section, i.e., the relationship between family ownership and dividend in Malaysian publicly listed firms, the following hypothesis was developed based on the review of the literature and research gaps in the previous studies. Firms controlled by family shareholders are found everywhere in the world especially in developing countries (Carney \& Child, 2013; Claessens et al., 2001; La Porta et al., 1999) including Malaysia. The association between family ownership and the dividend was examined through agency theory perspective. Controlling family shareholders have stronger incentives to monitor managers (Easterbrook, 1984; Jensen, 1986; Rozeff, 1982; Shleifer \& Vishny, 1986) and thus, they can reduce Type 1 agency conflict. However, the power and control of controlling family shareholders can give rise to another type of agency conflict (Type 2), and they can thus influence the dividend decision in the family firms (Mehboob et al., 2015).

The prevalence of ownership by the controlling family shareholders and legal protection for shareholders in Malaysia (Faccio et al., 2001) would anticipate a favourable positive relationship between family ownership and dividend. Family shareholders will pay high dividends to safeguard their reputation in the firm, consistent with the argument of Benjamin et al. (2016), Weisskopf (2010) and Schmid et al. (2010). Reputation is important in family firms as it enables the raising of capital in the future. Furthermore, high dividends can also overcome agency conflicts (both Type 1 and Type 2) as dividend can substitute monitoring role on the management (Anderson \& Reeb, 2003; Pindado et al., 2012). By transferring cash to shareholders through dividends, agency conflict on cash can be reduced. Family shareholders may also pay high dividends as dividends are the only source of income for family members, as argued by Carney \& Gedajlovic (2002) and Isakov and Weisskopf (2014; 2015). Hence, dividends can satisfy the income needs of the family shareholders. However, high dividends can also be paid for expropriation initiatives by the family shareholders. Since the family shareholders are the major shareholders in the firm, a large portion of dividends are paid to themselves; hence, they can disgorge cash indirectly. This behaviour of 'masking' expropriation with high dividends usually happens in the environment with strong legal protection for the minority shareholders (Faccio et al., 2001). Family shareholders do not want their expropriation activities to be known to the regulators and the other shareholders. 
Therefore, it is expected that family ownership may significantly positive in influencing dividend policy in Malaysia. The proposed hypothesis is as follows:

Hypothesis 1 (H1):

Family ownership is significantly positive in influencing dividend policy in Malaysia.

\section{Models and Data Description}

\subsection{Models and Measurement of Variables}

To achieve the aims of this study, the following equation was formulated to answer research question raised in the introduction section.

$$
\begin{gathered}
D Y_{i t}=\alpha_{0}+\beta_{1} F O_{i t}+\beta_{2} R O A_{i t}+\beta_{3} D R_{i t}+\beta_{4} S G_{i t}+\beta_{5} M B V_{i t}+\beta_{6} F S_{i t}+B S_{i t}+ \\
\beta_{8} I D R_{i t}+\beta_{9} D U M_{-} I N D_{i t}+\beta_{10} D U M_{-} Y R_{i t}+\epsilon_{i t}
\end{gathered}
$$

The dependent variable, dividend (DY) is measured by the dividend yield ratio, defined as the value of the cash dividends paid divided by market capitalisation. Cash dividends paid during the year excludes share repurchases because it was rarely practiced by Malaysian firms, consistent with the approach used by Miko and Kamardin (2015) and Benjamin et al. (2016). The use of dividend yield as the dependent variable is consistent with Gonzalez et al. (2014) and Ramli (2010).

The independent variable used in the study is family ownership. Family ownership is defined as the percentage of share ownership of founders and their related family members over total shares in the firm. The ownership of family shareholders was identified from direct and indirect (ownership through the other firms that own the firms in the study) shareholdings of the firm. The sections of directors' profile, list of 30 largest shareholders, list of substantial shareholders and directors' shareholdings in the annual report were referred to in order to identify the ownership of the family shareholders. The family relationship of the shareholders and directors are usually disclosed in those sections of the annual report based on the provisions of Companies Act, 1965 under Section 69D (1) and Bursa Malaysia Listing requirements. The definition of family relationship is also provided in Section 122A, Malaysian Companies Act, 1965, which defines family members as the spouse, parent, child, brothers or sisters and the spouse of that child, brothers or sisters. The shareholders were considered from the same family of the controlling shareholders if their surname is the same. Malay and Indian shareholders from the same family share the same father's name after their own given name. However, for the Chinese shareholders, they share the same surname at the beginning of their name. The same could also be applied to shareholders from other races (other than Malay, Chinese and Indians) as well. After identification of the family shareholders, their percentage was summed up to determine the family ownership of the firm. A firm is categorised as a family firm if the firm is owned by a family member or group of family members who collectively owned at least $10 \%$ or more of the total shareholdings. This definition of family firms is consistent with the study by Chen et al. (2005), La Porta et al. (1999) and Claessens et al. (2001).

The control variables used in the study are profitability (return on assets, ROA), debt (debt to assets ratio), sales growth (change in sales over a one-year period), investment opportunities (market-to-book ratio, MBV) and firm size (natural log of total assets at the end of the financial year). The control variables that are related to the governance characteristics are board size (number of directors on the board) and board independence (ratio of independent directors over the total number of directors). These control variables are used in the study as they are found to be statistically significant in influencing dividends in past studies. Table 1 lists the variables used in the study, their measurements, expected signs and the prior studies that had used these measurements. 
Table 1. Measurement of variables

\begin{tabular}{|c|c|c|c|c|}
\hline Variables & Notation & Explanation & Previous works & $\begin{array}{l}\text { Expected } \\
\text { Sign }\end{array}$ \\
\hline \multicolumn{5}{|c|}{ Dependent Variable } \\
\hline Dividend & DY & $\begin{array}{l}\text { Cash dividends divided by market capitalization } \\
\text { (total market value of common shares at the end of } \\
\text { the year }\end{array}$ & $\begin{array}{l}\text { Gonzalez et al. (2014); Ramli } \\
\text { (2010) }\end{array}$ & \\
\hline \multicolumn{5}{|c|}{ Independent Variables } \\
\hline $\begin{array}{l}\text { Family } \\
\text { Ownership }\end{array}$ & FO & $\begin{array}{l}\text { Percentage of share ownership of the founders and } \\
\text { their family members over the total shareholdings in } \\
\text { the firm }\end{array}$ & $\begin{array}{l}\text { Chen et al. (2005), La Porta et al. } \\
\text { (1999); Claessens et al. (2001) }\end{array}$ & + \\
\hline \multicolumn{5}{|c|}{ Control Variables } \\
\hline Profitability & $\mathrm{ROA}$ & $\begin{array}{l}\text { Total earnings before interest and taxes divided by } \\
\text { total assets }\end{array}$ & $\begin{array}{l}\text { Ahmad et al. (2003); Benjamin et } \\
\text { al. (2016) }\end{array}$ & + \\
\hline Debt & DR & Total debt over total assets & $\begin{array}{l}\text { Al-Maskati et at. (2015); Bokpin } \\
\text { (2011) }\end{array}$ & - \\
\hline Sales Growth & SG & $\begin{array}{l}\text { Annual growth rate of the total sales of a firm for a } \\
\text { certain year as compared to the previous year }\end{array}$ & $\begin{array}{l}\text { Hoechle et al. (2012); Bokpin } \\
\text { (2011) }\end{array}$ & - \\
\hline $\begin{array}{l}\text { Investment } \\
\text { Opportunities }\end{array}$ & MBV & $\begin{array}{l}\text { Market to book value ratio of the ordinary shares } \\
\text { capital }\end{array}$ & Fenn \& Liang (2001) & - \\
\hline Firm Size & FS & Natural logarithm of total assets & $\begin{array}{l}\text { Ahmad et al. (2003); Kang \& Lee } \\
\text { (2014) }\end{array}$ & + \\
\hline Board Size & BS & Number of directors on the board (BODs) & Ramli (2010) & + \\
\hline $\begin{array}{l}\text { Board } \\
\text { Independence }\end{array}$ & IDR & $\begin{array}{l}\text { Proportion of independent directors over the total } \\
\text { number of directors on the board. }\end{array}$ & Benjamin et al. (2016); & + \\
\hline \multicolumn{5}{|c|}{ Dummy Variables } \\
\hline Sector Dummy & DUM_IND & $\begin{array}{l}\text { Industry dummy, value equals to } 1 \text { if the firms are in } \\
\text { examined sectors (industries) or } 0 \text { for otherwise. }\end{array}$ & Gaur \& Kumar (2009); Hoechle & $\mathrm{n} / \mathrm{a}$ \\
\hline Year Dummy & DUM_YR & $\begin{array}{l}\text { Year dummy, value equals to } 1 \text { for the examined } \\
\text { years or } 0 \text { for otherwise. }\end{array}$ & et al. (2012); Park \& Jang (2013) & $\mathrm{n} / \mathrm{a}$ \\
\hline
\end{tabular}

\subsection{Data Description and Research Methodology}

The data of the study is all firms listed on the main market of Bursa Malaysia. All the sectors of firms listed on the main market are included in the data of the study except firms from Finance (governed by different set of regulations) and Mining sectors (only one firm in this sector). The exclusion of firms in the finance sector is consistent with Lins and Sarvaes (2012) and Ramli (2010) while the exclusion of firms in the mining sector is consistent with Benjamin et al. (2016).

The data of firms used in the study were collected from the Bloomberg terminal and the annual reports of firms that can be downloaded from firm's website or the Bursa Malaysia's website. Initially, data from 734 firms are gathered. However, some of the observations of the firms were having missing values which resulted in the exclusion of these observations in the data of this study. Thus, the final number of firms used in the study reduced to 712 firms, with 2,900 firm-year observations across five (5) years period of analysis from the year 2010 to 2014. These observations are classified as unbalanced panel dataset as some of the firms may not have all the observations across the period of the study.

The data of the study were examined using descriptive statistics; to provide general overview of the data, non-parametric Kruskal Wallies (chi-squared) test; to test mean differences across the types of firm, correlation analysis; to determine the possible closeness of the relationship and finally using Ordinary Least Square (OLS) regression analysis; to examine the association between the experimental variable(s) with the dependent (outcome) variable. The results of the study are presented in the next section.

\section{Results}

\subsection{Descriptive Statistics}

Table 2 presents the results of descriptive statistics for the variables used in the study. 
Table 2. Descriptive Statistics (Based on original values)

\begin{tabular}{|c|c|c|c|c|c|c|c|}
\hline \multirow{2}{*}{ Variables } & \multicolumn{2}{|l|}{ All firms } & \multicolumn{2}{|c|}{ Family Firms (a) } & \multicolumn{2}{|c|}{ Non-family Firms (b) } & Difference \\
\hline & Mean & Std Dev. & Mean & Std Dev. & Mean & Std Dev. & $\begin{array}{l}\text { in Mean } \\
\text { (a) - (b) }\end{array}$ \\
\hline Dividend (DY) & 2.4732 & 5.2723 & 2.5024 & 5.5908 & 2.2981 & 2.6482 & 0.2043 \\
\hline Family Ownership (FO) & 36.1301 & 21.0790 & 42.0863 & 16.41 & 0.3643 & 1.6614 & $41.722 * * *$ \\
\hline Profitability (ROA) & 0.0612 & 0.1213 & 0.0604 & 0.1172 & 0.0656 & 0.1437 & -0.0052 \\
\hline Debt (DR) & 0.3842 & 0.2718 & 0.3821 & 0.2813 & 0.3962 & 0.2054 & -0.0141 \\
\hline Sales growth (SG) & 15.0127 & 110.4597 & 16.1354 & 118.2676 & 8.2715 & 37.8445 & 7.8639 \\
\hline $\begin{array}{l}\text { Investment } \quad \text { opportunities } \\
(\mathrm{MBV})\end{array}$ & 3.0266 & 7.3064 & 2.4971 & 4.6683 & 6.2067 & 15.2236 & $3.7096 * * *$ \\
\hline Firm size (FS) & 2.6778 & 0.6464 & 2.6416 & 0.6163 & 2.8950 & 0.7695 & $-0.2534 * * *$ \\
\hline Board size (BS) & 7.5566 & 2.0889 & 7.5046 & 2.0118 & 7.8672 & 2.4827 & $-0.3626 * *$ \\
\hline Board independence (IDR) & 0.4539 & 0.1289 & 0.4521 & 0.1292 & 0.4648 & 0.1264 & $-0.0127 * *$ \\
\hline $\mathrm{N}$ & 2,900 & & 2,486 & & 414 & & \\
\hline
\end{tabular}

Note. DY is measured by dividend yield (cash dividends over market capitalisation), FO is measured by the percentage of share ownership of the founders and their family members over the total shareholdings in the firm, ROA is measured by total earnings before interest and taxes divided by total assets, DR is measured by total debt over total assets, SG is annual growth rate of the total sales of a firm for a certain year as compared to the previous year, MBV is market to book value ratio of shares capital, FS is natural logarithm of total assets, BS is number of directors in the Board (BODs) and IDR is proportion of independent directors over the total number of directors' in the board. ***,** \& * stand for the significance at $1 \%, 5 \% \& 10 \%$ level, respectively.

The means and standard deviations were presented for the overall data in the above table. The overall data is divided into family firms (FFs) and non-family firms (NFFs) in order to observe any significant differences in the variables based on the types of firm. The basis used to classify FFs was justified in the variable section. The differences in mean between FFs and NFFs were analysed using non-parametric Kruskal-Wallis (chi-squared) test.

On average, RM 2.47 of dividends were paid for every RM 1 of the share price by publicly listed firms in Malaysia with FFs were paid slightly higher dividends compared to their NFFs counterparts (2.50 vs 2.30), although the mean dividend between these two groups was statistically insignificant. Higher dividend pay-outs among FFs is consistent with the previous study such as Isakov and Weisskopf (2015) and Benjamin et al. (2016).

In terms of family ownership (FO), mean FO for the overall public firms in Malaysia was 36.13\%, while in FFs was $42.09 \%$. This result is consistent with the previous studies such as the one by Carney and Child (2013) and Claessens et al. (2001). For the value of standard deviation, both FFs and NFFs were having lower standard deviations as compared to the overall firms. This indicates that the data are closer to the mean sample if it is characterised by respective types of firm.

Mean profitability for Malaysian firms was 0.06 for every ringgit of total assets invested in the firm while the standard deviation was close to 0 indicating that most of the observations are close to mean sample and not spread out over a wider range. FFs were having slightly lower profitability ratio as compared to the NFFs, consistent with Mulyani et al. (2016) and Huei (2012). However, as discussed earlier, FFs were seen to pay high dividends although its profitability ratio is low than NFFs. On a preliminary notes, this seems to indicate that FFs were tended to expropriate resources against minority shareholders by disbursing dividends to its shareholders although it generates lower profits than NFFs. However, this remark needs to be confirmed with the regression analysis (discussed in regression section) before reach to the conclusion. The difference in mean profitability between FFs and NFFs is statistically insignificant. In the case of debt, mean debt ratio of 0.38 indicates that Malaysian firms were using 38 cents of total debts for every Ringgit of their total assets. FFs employ slightly lower mean debt components $(0.3821)$ as their financing method compared to NFFs $(0.3962)$, and this is consistent with Mulyani et al. (2016). This may due to the reason that FFs usually depend on their own financial resources to finance the development activities in the firm (Anderson et al., 2003). Also, FFs usually do not have strong collateral to secure facility from the capital provider. The mean difference for debt ratio between FFs and NFFs is statistically insignificant. For the variable of sales growth, mean sales growth for the overall firms in Malaysia was $15.01 \%$, shows that the revenue of the firm in certain year grows by $15.01 \%$ compared with the revenue of previous year. Higher mean sales growth was found for FFs (16.14) as compared to NFFs (8.27) and 
this is consistent with Benjamin et al. (2016). Family shareholders tend to work hard to expand revenue of their business as the family business is their only source of income. Hence, its business growth usually higher than that of the other types of firm. Mean difference for sales growth for FFs and NFFs is statistically insignificant as well. For investment opportunities (MBV), the Malaysian public firms were having 3.03 market book value ratio. This shows that market value of firms in Malaysia is three (3) times higher than its book value. Higher market price compared to the book price describes that the company has higher investment prospects (La Porta et al., 1997; Frank \& Goyal, 2003); hence, the investors would place higher trust on the future of the firm. NFFs were found to be highly trusted by the investors as the mean market book value ratio for these firms was extremely high at 6.21 on average compared to the FFs with the value of 2.49, consistent with Benjamin et al. (2016) and Korajkczyk and Levy (2003). The high trust placed on the NFFs may be due to the controlling ownership of these firms; these firms are generally controlled by the government related shareholders, institutional shareholders and/or foreign shareholders. The mean difference of investment opportunities is statistically significant (p-value $<0.01$ ) between FFs and NFFs. In the case of firm size, the mean value for all firm is 2.67 and NFFs were recorded as larger in size (2.90) as compared to FFs (2.64). This is consistent with Benjamin et al. (2016). As discussed earlier, NFFs are usually managed by either government related shareholders, institutional and/or foreign shareholders who usually have a substantial amount of fund which can be used to incorporate larger firm compared to the firm incorporated by the family shareholders. Additionally, the NFFs are also usually assemble large management team (Van-den-Berghe $\&$ Carchon, 2001). Mean firm size between FFs and NFFs are statistically significant difference from 0 (p-value $<0.01$ ).

The mean board size for Malaysian public firms was 7.6 (or 8 ) members. FFs are having slightly smaller mean board size (7.50) as compared to NFFs (7.87) and the mean difference is statistically significant at $5 \%$ level. Large board size could contribute efficiently to the management of the firm as the members are from different professional backgrounds (Ramli, 2010). As mentioned earlier, the type of ownership in NFFs usually assemble larger board size as they have sufficient resources to do so and they need to appoint affiliate personnel from the business networks to be the directors of the firm. On the aspect of independence of the board, the Malaysian public firm was having mean $45 \%$ of board independence. This average board independence ratio is in compliance to the Malaysian Code of Corporate Governance 2012 (MCCG, 2012) which requires that independent directors must make up at least one-third (1/3) of the board size of Malaysian public firms (Securities Commission, 2017). FFs are having weaker board independence (0.45) as compared to NFFs $(0.46)$. This again may indicate that FFs may involve in the expropriation activities, thus employing weaker board could be beneficial as the influence of the independent directors on the affairs of the firm may not be strong (Setia-Atmaja et al., 2009). Both board size and board independence for FFs and NFFs are having mean differences that are statistically significant at least at $5 \%$ level.

\subsection{Regression Analysis}

In order to test the models of the study, regression analysis was carried out. However, correlations analysis was first performed to ensure no issues on multicollinearity.

Table 3. Correlation analysis (Pairwise Correlation) for all firm

\begin{tabular}{llllllllll}
\hline & DY & FO & ROA & DR & SG & MBV & FS & BS & IDR \\
\hline DY & 1 & & & & & & & & \\
FO & $0.1029^{* * *}$ & 1 & & & & & & & \\
ROA & $0.3100^{* * *}$ & 0.0185 & 1 & & & & & & \\
DR & $-0.1574^{* * *}$ & $-0.0880^{* * *}$ & $-0.0985^{* * *}$ & 1 & & & & & \\
SG & -0.0107 & 0.0208 & $0.0868^{* * *}$ & $0.0563^{* * *}$ & 1 & & & & \\
MBV & $0.0987^{* * *}$ & $-0.0945^{* * *}$ & $0.4928^{* * *}$ & $0.0665^{* * *}$ & 0.0122 & 1 & & & \\
FS & $0.0613^{* * *}$ & -0.0108 & $0.1237^{* * *}$ & $0.2586^{* * *}$ & $0.0343^{*}$ & $0.2965^{* * *}$ & 1 & & \\
BS & $0.0791^{* * *}$ & $-0.0314^{*}$ & $0.1079^{* * *}$ & $0.0862^{* * *}$ & 0.021 & $0.1406^{* * *}$ & $0.3402^{* * *}$ & 1 & \\
IDR & $-0.1027^{* * *}$ & $-0.0491^{* * *}$ & $-0.0891^{* * *}$ & -0.0013 & -0.0153 & -0.0249 & -0.0097 & $-0.3628^{* * *}$ & 1 \\
\hline
\end{tabular}

Note. DY is measured by dividend yield (cash dividends over market capitalisation), FO is measured by the percentage of share ownership of the founders and their family members over the total shareholdings in the firm, ROA is measured by total earnings before interest and taxes divided by total assets, DR is measured by total debt over total assets, SG is annual growth rate of the total sales of a firm for a certain year as compared to the previous year, MBV is market to book value ratio of shares capital, FS is natural logarithm of total assets, BS is number of directors in the Board (BODs) and IDR is proportion of independent directors over the total number of directors' in the board. ***,**\&* stand for the significance at $1 \%, 5 \% \& 10 \%$ level, respectively. 
From the correlation analysis, none of the variables were highly correlated with the dependent variable (the maximum correlation is 0.31 ). Thus, the issue of multicollinearity was ruled out on these models of analyses. Multicollinearity only arises if the pairwise correlation coefficient between two variables is above -0.7 or below 0.7 (Gujarati \& Porter, 2009). All variables except SG were significantly correlated at least at $5 \%$ significance level ( $\mathrm{p}$-value $<0.05$ ). The regression results of the models examined in the study are presented in Table 4.

Table 4. Robust clustered by firm estimation

\begin{tabular}{llll}
\hline Variables & All firms & Family firms & Non-family firms \\
\hline FO & $0.0122^{* *}[0.0055]$ & $0.0213^{* *}[0.0090]$ & -0.0236 \\
ROA & $10.9330^{* * *}[1.4518]$ & $12.419^{* * *}[1.8132]$ & {$[0.1022]$} \\
DR & $-2.1949^{* * *}[0.3492]$ & $-1.8995^{* * *}[0.3996]$ & $6.1003^{* * *}[1.3927]$ \\
SG & $-0.0016^{* * *}[0.0005]$ & $-0.0016^{* * *}[0.0004]$ & $-2.404 * * *[0.8365]$ \\
MBV & $-0.0338^{*}[0.0191]$ & $-0.023787[0.0274]$ & $-0.003489[0.0048]$ \\
& & 0.160238 & -0.017161 \\
FS & $0.3573^{* *}[0.1411]$ & {$[0.1781]$} & {$[0.0149]$} \\
& & $0.0402442[0.0434]$ & $0.83211^{* * *[0.2719]}$ \\
BS & $0.342 \quad[0.0396]$ & $-1.4452^{* *}[0.6572]$ & -0.05003 \\
IDR & $-1.6522^{* * *}[0.5918]$ & $1.51458^{* * *}[0.5902]$ & {$[0.0885]$} \\
Intercept & $1.7927 * * * 0.5228]$ & $-2.489 * *$ & {$[1.2525]$} \\
\hline
\end{tabular}

Note. DY is measured by dividend yield (cash dividends over market capitalisation), FO is measured by the percentage of share ownership of the founders and their family members over the total shareholdings in the firm, ROA is measured by total earnings before interest and taxes divided by total assets, DR is measured by total debt over total assets, SG is annual growth rate of the total sales of a firm for a certain year as compared to the previous year, MBV is market to book value ratio of shares capital, FS is natural logarithm of total assets, BS is number of directors in the Board (BODs) and IDR is proportion of independent directors over the total number of directors' in the board. ***,** \&* stand for the significance at $1 \%, 5 \% \& 10 \%$ level, respectively.Coefficient*** [Standard error]; Significance levels: $* * *$ Significant at $1 \%$, **Significant at $5 \%$, *Significant at $10 \%$

Based on the regression results for the examined model, family ownership (FO) was recorded to be significantly positive in influencing DY (p-value $<0.05$ ) in all firms, especially in FFs. However, FO turned out to be negatively influence DY and the relationship was statistically insignificant in NFFs. In terms of the control variables, ROA, FS and BS showed positive influence coefficient with DY while DR, SG, MBV and IDR had negative influence coefficient with DY for all firms and FFs. For NFFs, only ROA and FS positively influenced DY while the rest of the variables were negatively influencing DY. Furthermore, all the variables in all firms were statistically significant (at least at 5\% level) in influencing DY except BS which had an insignificant relationship with DY. For FFs, ROA, DR, SG and IDR were statistically significant (at least at 5\% level) in influencing DY, while for NFFs, ROA, DR, FS and IDR were statistically significant (at least at $1 \%$ level) in influencing DY.

The above regression results were presented by using robust clustered by firm estimation to deal with those failures in meeting assumptions on normality, auto-correlation, heteroscedasticity and observations with large residuals (Petersen, 2009). Petersen (2009) has confirmed that analysis using panel data are usually confronted by the firm-effect and time-effect. Therefore, the standard errors of the original OLS estimation could be biased across firm-effect and time-effect. Estimating regressions using robust cluster by firm-effect could produce unbiased results. However, estimating regression using robust cluster by time-effect may not necessary, as the data used in the study only covers for the period of five (5) years. Hence, a short period of time may not have time based cluster effect.

\subsection{Tests of Endogeneity}

Additional analysis on endogeneity test was performed to test for the robustness of associations. This endogeneity test can detect the reverse causality between dependent and independent variables in the models of the study. The issue of endogeneity in the regression can be overcome through the application of Granger Causality (GC) test (Granger, 1969). Two types of GC test were performed. First, the simple univariate test between the suspected lagged dependent variable and the current value of experimental variables was carried out. Next, the more detail GC effects (bivariate test) was carried out through simultaneous equation model consistent 
with Hu and Izumida (2008). The following Table 5 and 6 present the results of the above tests:

Table 5. Granger causality test (univariate test)

\begin{tabular}{lllll}
\hline Models & F-Statistic & P-value & $\begin{array}{l}\text { Hypothesis } \\
\text { Result } \\
\text { (significant) }\end{array}$ & Endogeneity \\
\hline Model & & & & \\
FO $_{\mathrm{t}-1}$ does not granger causes DY & 1.89 & 0.1698 & Insignificant & NO \\
$\mathrm{DY}_{\mathrm{t}-1}$ does not granger causes FO & 0.01 & 0.9039 & Insignificant & \\
\hline
\end{tabular}

Note. DY is measured by dividend yield (cash dividends over market capitalisation) and FO is measured by the percentage of share ownership of the founders and their family members over the total shareholdings in the firm.

Table 6. Granger causality test (bivariate test)

\begin{tabular}{lllll}
\hline \multirow{2}{*}{ Variables } & \multicolumn{2}{l}{ Dependent Variable: DY } & \multicolumn{2}{l}{ Dependent Variable: FO } \\
\cline { 2 - 5 } & Coefficient & t-statistics & Coefficient & t-statistics \\
\hline DY(t-1) & 0.6161 & $42.82^{* * *}$ & -0.0048 & -0.12 \\
FO(t-1) & 0.0031 & 1.37 & 0.9650 & $155.36^{* * *}$ \\
ROA & 5.5990 & $9.22^{* * *}$ & -0.2150 & -0.13 \\
DR & -0.8062 & $-3.21^{* * *}$ & 0.0165 & 0.02 \\
SG & 0.0001 & 0.16 & 0.0005 & 0.23 \\
MBV & -0.0272 & $-3.24^{* * *}$ & -0.0171 & -0.74 \\
FS & 0.2263 & $2.74^{* * *}$ & 0.0991 & 0.44 \\
BS & -0.0041 & -0.16 & -0.0532 & -0.75 \\
IDR & -0.8879 & $-2.21^{* *}$ & -2.3560 & $-2.14^{* *}$ \\
Cons & $1.90^{*}$ & 2.6643 & $2.8^{* * *}$ \\
N & 0.6583 & & 2031 & \\
Ind. Dummy & 2031 & & Yes & \\
Yr. Dummy & Yes & & Yes & \\
R-Squared & Yes & & 0.9256 & \\
\hline
\end{tabular}

Note. DY is measured by dividend yield (cash dividends over market capitalisation), FO is measured by the percentage of share ownership of the founders and their family members over the total shareholdings in the firm, ROA is measured by total earnings before interest and taxes divided by total assets, DR is measured by total debt over total assets, SG is annual growth rate of the total sales of a firm for a certain year as compared to the previous year, MBV is market to book value ratio of shares capital, FS is natural logarithm of total assets, BS is number of directors in the Board (BODs) and IDR is proportion of independent directors over the total number of directors' in the board. ***,** $\& *$ stand for the significance at $1 \%, 5 \% \& 10 \%$ level, respectively.

Based on the univariate GC test in Table 5, lagged one-year value of the dependent variable is tested against the current value of the independent variable (experimental variables) to detect any presence of endogeneity in the model used in the study, which can cause the estimation to be biased. The results show that DY does not granger causes any of the experimental variables (FO) in the study. This is shown by the p-value, which is higher than the $5 \%$ significance level. Hence, this GC test rules out the presence of endogeneity problem in the model.

Based on the detailed GC test (bivariate test) in Table 6, the presence of endogeneity is confirmed (reverse causality) if lagged one-year value of DY granger causes the current value of FO. The lagged one-year DY does not Granger causes the current value of FO, as is observed by the insignificant result. Hence, this test's results confirm that no endogeneity problem exists in the model of the study.

\section{Discussion of Results}

FO was found to be significantly positive in influencing the dividend policy of the firms in Malaysia, especially in family firms. This results support the hypothesis formulated for the model of the study. This positive association between family ownership and dividend policy is consistent with the previous study such as Schmid et al. (2010), Weisskopf (2010) and Benjamin et al. (2016) but contradicts the view that family ownership adversely affects dividend policy in studies by Mulyani et al. (2016), Aquenaou et al. (2013) and Gonzalez et al. (2014). In term of theory, this association is consistent with the agency theory which implies the conflict of interest arises between the internal (agent) and the external shareholders (principal) (Jensen \& Meckling, 1976). 
Further, the association shows that the presence of the controlling family shareholders in the firm especially in FFs can improve the monitoring role on the management of the firm. Hence, it can reduce the Type 1 agency conflict. In this case, the controlling family shareholders become an alternate governance provider in their firms, as highlighted by Pindado et al. (2012).

The first argument that supports the favourable association between FO and dividend is on the reputational view of dividend, as discussed by Benjamin et al. (2016), Schmid et al. (2010) and Weisskopf (2010). The reputation of the family shareholders is essential to raise capital for firms in the future (La Porta et al. 2000). This is because the payment of dividends and subsequent issue shares in the capital market is the disciplinary mechanism of the firms controlled by the family shareholders (Easterbrook 1984; Rozeff, 1982). By paying high dividends, the interest of the family and non-family shareholders can be aligned (Wiwattanakantang, 2001). Moreover, the future investors will also not lose trust in firms with high dividends (Carney \& Gedajlovic, 2002). Further, high dividends also indicate that ownership and control rights of the shareholders are not separated in the firm (Johnson et al., 2000; Morck \& Yeung, 2003).

Another argument that supports the positive relationship between family ownership and the dividend is the conventional view of the dividend that can reduce the agency conflict (both Type 1 and Type 2) in the firm (Anderson \& Reeb, 2003; Pindado et al., 2012), especially in the firms controlled by the family shareholders. Dividends can reduce the availability of the free cash flow in the firm, as discussed by Jensen (1986). By reduction of cash flow in the firm, either the managers or the controlling shareholders would not misuse the cash for the investments or projects that can only benefit them, rather than to all the shareholders. Further, strong legal protection for minority shareholders in Malaysia (Faccio et al. 2001) could also provide an opportunity for the minorities to exert pressure on the firm's management to pay high dividends. Thus, in this regards, dividends can substitute monitoring role of the external shareholders, especially for the minorities. Therefore, this scenario reaffirms the 'outcome model' proposed by La Porta et al. (2000). The strong governance structure protects the shareholders, especially in the firms controlled by the family shareholders.

Furthermore, frequent dividend payments are also important in the firms controlled by family shareholders as dividends can satisfy the income source for them (Carney \& Gedajlovic, 2002; Isakov \& Weisskopf, 2014, 2015). In this regard, dividends could be higher when there are additional family members (family ownership) in a firm as the consumption of income increases. Moreover, by paying high dividends to the family members, the controlling family shareholders could remain in control and absorb income in the long term. This view is consistent with the results found in the descriptive statistics, where family firms pay higher dividends than their non-family counterparts.

Finally, although high dividends negate the expropriation arguments in most previous studies, it could still justify the expropriation motive of the controlling shareholders, especially the family shareholders. This alternative explanation suggests that dividends can be the way to expropriate resources as it was paid to the controlling family shareholders (the majority shareholders) and their related family members. The controlling family shareholders have no choice to conduct this masking behaviour by paying high dividends to themselves, hence it will not trigger regulators to conduct negative action against the firms. The external shareholders will also strongly impress by this credible behaviour of paying high dividends, although in reality, the dividends reach mostly to the family shareholders as they are the majority shareholders in the firm. This argument is also consistent with the results found in the descriptive statistics (refer Table 2). The analysis showed that the family firms are paying high dividends although generate lower profits compared to their non-family counterparts. This clearly highlights the motive of expropriation by the controlling family shareholders.

In non-family firms (widely held by the family shareholders), family ownership is found to be insignificantly influence dividends. This result reaffirms the previous arguments that dividends do not provide reputation, reduce agency conflict and source of income to the family shareholders in the firms controlled by the non-family shareholders. Hence, family shareholders could not form alternate governance mechanism in the firms not controlled by them (in non-family firms). The minority share ownership does provide control and power to pressure the management of non-family firms.

\section{Conclusions}

The study examined the association between family ownership and dividend policy in Malaysia. It used data from 712 firms listed on the Bursa Malaysia, for the period of 5 years (from 2010 to 2014). Firms from Malaysia (the emerging market) is selected as the data of the study as it has the concentrated type of ownership among the family shareholders (Carney \& Child, 2013; Claessens et al., 2001) and it is different with the type of ownership in developed countries that are mostly dispersed in the hand of multiple types of shareholders. The concentrated 
and controlling type of ownership merely creates agency conflict that can influence the decision of dividend policy in these firms.

Based on the results of the study, payment of high dividends by the controlling family shareholders supported the arguments of reputational view of dividend, mitigation of agency conflict and source of income for family shareholders. These arguments are consistent with the results found in the past studies which highlight the behaviour of the controlling shareholders that are not into expropriation activities against the minority shareholders. However, in this context of the study, this view may not be relevant, especially in family firms. High dividend pay-outs can be an alternative of expropriation by the controlling family shareholders as the dividends were paid to themselves, the majority shareholders in the firm. In this regards, the interest of the family shareholders was the priorities even in the case of the dividend that can build the reputation, mitigate agency conflict and provide a source of income for the family shareholders. The controlling shareholders will not conduct expropriation activities directly as it will hurt the share price of the firm, thus it reduces the firm value. Since strong legal protection on shareholder is practiced in Malaysia (Faccio et al., 2001), family shareholders have no choice but to conduct this masking behaviour to transfer cash through dividends to their family members. Also, payment of high dividends can impress the minority shareholders in the firm (Pindado et al. 2012).

Although this study provides a significant contribution to the body of knowledge, it still has its limitations. Firstly, this study was conducted based on single country analysis, thus the results may not be applicable to the other emerging countries that have similar corporate structure. Comparison of results across multiple countries and the effort of the regulators in developing their corporate governance mechanisms can provide recommendations to develop better governance mechanism in Malaysia. For instance, the mechanism to control expropriation activities by the controlling family shareholders in the neighbouring countries that have larger and developed economies, such as from Singapore and Indonesia, can be learned.

Further, the next limitation is on the time period of analysis that only covers years after the Asian Financial Crisis. Although most of the firms in East Asian Countries are having concentrated and controlling type of ownership (Carney \& Child, 2013), the payment of dividends may vary across a long period. Firms may alter their dividend pay-outs depending on the economic environment of the country and this will clearly highlight the motive of the controlling shareholders. Thus, further studies have to consider the number of years of dividend pay-outs by the controlling family shareholders that may affect the relationship between the family ownership and dividend policy.

\section{References}

Ahmad, A. C., Ishak, Z., \& Abd, N. A. (2003). Corporate Governance, ownership structure and corporate diversification: Evidence from the Malaysian listed companies. Asian Academy of Management Journal, $8(2), 67-89$.

Al-Maskati, N., Bate, A. J., \& Bhabra, G. S. (2015). Diversification, corporate governance and firm value in small markets: Evidence from New Zealand. Accounting and Finance, 55(3), 627-657. https://doi.org/10.1111/acfi.12069

Anderson, R. C., Mansi, S. A., \& Reeb, D. M. (2003). Founding family ownership and the agency cost of debt. Journal of Financial Economics, 68(2), 263-285. https://doi.org/10.1016/S0304-405X(03)00067-9

Anderson, R., \& Reeb, D. (2003). Founding-family ownership, corporate diversification, and firm leverage. Journal of Law and Economics, 46(2), 653-684. https://doi.org/10.1086/377115

Aquenaou, S. F. O., \& Di, H. (2013). Dividend policy and ownership structure: Evidence from the Casablanca Stock Exchange. GSTF Business Review (GBR), 2(4), 116-121. https://doi.org/10.5176/2010-4804_2.4.259

Benjamin, S. J., Wasiuzzaman, S., Mokhtarinia, H., \& Rezaie, N. N. (2016). Family ownership and dividend pay-out in Malaysia. International Journal of Managerial Finance, 12(3), 314-334. https://doi.org/10.1108/IJMF-08-2014-0114

Bokpin, G. A. (2011). Ownership structure, corporate governance and dividend performance on the Ghana Stock Exchange. Journal of Applied Accounting Research, 12(1), 613. https://doi.org/10.1108/09675421111130612

Carney, M., \& Gedajlovic, E. (2002). The coupling of ownership and control and the allocation of financial resources: Evidence from Hong Kong. Journal of Management Studies, 39(1), 123-146. https://doi.org/10.1111/1467-6486.00285 
Carney, R. W., \& Child, T. B. (2013). Changes to the ownership and control of East Asian corporations between 1996 and 2008: The primacy of politics. Journal of Financial Economics, 107(2), 494-513. https://doi.org/10.1016/j.jfineco.2012.08.013

Chen, Z., Cheung, Y. L., Stouraitis, A., \& Wong, A. W. S. (2005). Ownership concentration, firm performance and dividend policy in Hong Kong. Pacific-Basin Finance Journal, 13(4), 431-449. https://doi.org/10.1016/j.pacfin.2004.12.001

Claessens, S., Djankov, S., Fan, J., \& Lang, L. (2001). The pattern and valuation effects of corporate diversification: A comparison of the United States, Japan, and other East Asian economies (No. 2001/127). WIDER Discussion Papers//World Institute for Development Economics (UNU-WIDER). Retrieved from http://hdl.handle.net/10419/52941

Easterbrook, F. H. (1984). Two agency-cost explanations of dividends. The American Economic Review, 74(4), 650-659.

Eisenhardt, K. M. (1989). Building theories from case study research. Academy of Management Review, 14(4), 532-550. https://doi.org/10.5465/AMR.1989.4308385

Faccio, M., Lang, L. H. P., \& Young, L. (2001). Dividends and expropriation. American Economic Review, 91(1), 54-78. https://doi.org/ 10.1257/aer.91.1.54

Fama, E., \& Jensen, M. (1983). Separation of ownership and control. Journal of Law and Economics, 26(2), 301-325. https://doi.org/10.1086/467037

Fenn, G. W., \& Liang, N. (2001). Corporate pay-out policy and managerial stock incentives. Journal of Financial Economics, 60(1), 45-72. http://doi.org/10.1016/S0304-405X(01)00039-3

Frank, J., \& Meyers, N. L. (1933). The Modern Corporation and private property. McMillan, NewYork. https://doi.org/10.2307/790998

Frank, M. Z., \& Goyal, V. K. (2003). Testing the pecking order theory of capital structure. Journal of Financial Economics, 67(2), 217-248. https://doi.org/10.1016/S0304-405X(02)00252-0

Gaur, A. S., \& Kumar, V. (2009). International diversification, business group affiliation and firm performance: Empirical evidence from India. British Journal of Management, 20(2), 172-186. https://doi.org/10.1111/j.1467-8551.2007.00558.x

Ghee, W. Y., Ibrahim, M. D., \& Abdul-Halim, H. (2015). Family business succession planning: Unleashing the key factors of business performance. Asian Academy of Management Journal, 20(2), 103-126.

González, M., Guzmán, A., Pombo, C., \& Trujillo, M. A. (2014). Family involvement and dividend policy in closely held firms. Family Business Review, 27(4), 365-385. https://doi.org/10.1177/0894486514538448

Granger, C. W. (1969). Investigating causal relations by econometric models and cross-spectral methods. Econometrica: Journal of the Econometric Society, 37(3), 424-438. https://doi.org/10.2307/1912791

Gugler, K., \& Yurtoglu, B. B. (2003). Corporate Governance and dividend pay-out policy in Germany. European Economic Review, 47(4), 731-758. https://doi.org/10.1016/S0014-2921(02)00291-X

Gujarati, D. N., \& Porter, D. (2009). Basic Econometrics. Mc Graw-Hill International Edition.

Hoechle, D., Schmid, M., Walter, I., \& Yermack, D. (2012). How much of the diversification discount can be explained by poor corporate governance? Journal of Financial Economics, 103(1), 41-60. https://doi.org/10.1016/j.jfineco.2011.03.025

Holder, M. E., Langrehr, F. W., \& Hexter, J. L. (1998). Dividend policy determinants: An investigation of the influences of stakeholder theory. Financial management, 27(3), 73-82. https://doi.org/ 10.2307/3666276

Hu, Y., \& Izumida, S. (2008). Ownership concentration and corporate performance: A causal analysis with Japanese panel data. Corporate Governance: An International Review, 16(4), 342-358. https://doi.org/10.1111/j.1467-8683.2008.00690.x

Huei, N. S. (2012). The influence of ownership, control, governance and diversification on the performance of family controlled-firms in Malaysia. Unpublished PhD Thesis. University of Northumbria, Newscastle.

Isakov, D., \& Jean-Philippe, W., (2015). Pay-out policies in founding family firms. Journal of Corporate Finance, 33(1), 330-344. https://doi.org/10.1016/j.jcorpfin.2015.01.003

Isakov, D., \& Weisskopf, J. P. (2014). Are founding families special blockholders? An investigation of 
controlling shareholder influence on firm performance. Journal of Banking and Finance, 41(1), 1-16. https://doi.org/10.1016/j.jbankfin.2013.12.012

James, H. (1999). Owner as manager, extended horizons and the family firm. International Journal of the Economics of Business, 6(1), 41-56. https://doi.org/10.1080/13571519984304

Jensen, M. C. (1986). Agency costs of free cash flow, corporate finance, and takeovers. The American Economic Review, 76(2), 323-329.

Jensen, M. C., \& Meckling, W. H. (1976). Theory of the firm: Managerial behaviour, agency costs and ownership structure. Journal of Financial Economics, 3(4), 305-360. https://doi.org/10.1016/0304-405X(76)90026-X

Johnson, S., Boone, P., Breach, A., \& Friedman, E. (2000). Corporate Governance in the Asian financial crisis. Journal of Financial Economics, 58(1-2), 141-186. https://doi.org/10.1016/S0304-405X(00)00069-6

Kang, K. H., \& Lee, S. (2014). The moderating role of brand diversification on the relationship between geographic diversification and firm performance in the US lodging industry. International Journal of Hospitality Management, 38(1), 106-117. https://doi.org/10.1016/j.ijhm.2013.01.001

Korajczyk, R., \& Levy, A. (2003). Capital structure choice: Macroeconomic conditions and financial constraints. Journal of Financial Economics, 68(1), 75-109. https://doi.org/10.1016/S0304-405X(02)00249-0

La Porta, R., Lopez-de-Silanes, F., \& Shleifer, A. (1999). Corporate ownership around the world. The Journal of Finance, 54(2), 471-517. http://doi.org/10.1111/0022-1082.00115

La Porta, R., Lopez-de-Silanes, F., Shleifer, A., \& Vishny, R. W. (2000). Agency problems and dividend polices around the world. The Journal of Finance, 55(1), 1-33. https://doi.org/10.1111/0022-1082.00199

La Porta, R., Lopez-de-Silanes, F., Shleifer, A., \& Vishny, R. W. (1997). Legal determinants of external finance. The Journal of Finance, 52(3), 1131-1150. https://doi.org/10.2307/2329518

Lang, L. H. P., \& Litzenberger, R. H. (1989). Dividend announcements: Cash flow signalling vs free cash flow hypothesis? Journal of Financial Economics, 24(1), 181-191. http://doi.org/10.1016/0304-405X(89)90077-9

Lins, K. V., \& Servaes, H. (2002). Is corporate diversification beneficial in emerging markets? Financial Management, 31(2), 5-31. https://doi.org/10.2307/3666220

Lv, H., Li, W., \& Gao, S. S. (2012). Dividend tunnelling and joint expropriation: Empirical evidence from China's capital market. European Journal of Finance, 18(3-4), 369-392. http://doi.org/10.1080/1351847X.2011.579741

Malaysian Code of Corporate Governance 2012. Retrieved from https://www.sc.com.my/wp-content/uploads/eng/html/cg/cg2012.pdf

Mancinelli, L., \& Ozkan, A. (2006). Ownership structure and dividend policy: Evidence from Italian firms. The European Journal of Finance, 12(3), 265-282. https://doi.org/10.1080/13518470500249365

Mehboob, F., Tahir, S. H., \& Hussain, T. (2015). Impact of family ownership on financial decisions of a firm: An analysis of pharmaceutical and chemical sectors in Pakistan, 184(4), 103-112.

Miko, N. U., \& Kamardin, H. (2015). Ownership structure and dividend policy of conglomerate firms in Nigeria. Academic Journal of Interdisciplinary Studies, 4(2), 279-286. https://doi.org/10.5901/ajis.2015.v4n2p279

Miller, M., \& Modigliani, F. (1958). The cost of capital, corporation finance and the theory of investment. American Economic Association, 48(3), 261-297.

Mishra, C. S., Randoy, T., \& Jenssen, J. I. (2001). The effect of founding family influence on firm value and Corporate Governance. Journal of International Financial Management and Accounting, 12(3), 235-259. https://doi.org/10.1111/1467-646X.00073

Mitnick, B. M. (1973). Fiduciary rationality and public policy: The theory of agency and some consequences. Proceedings of the 1973 Annual Meeting of the American Political Science Association, NewOrleans, LA, 69. UMI, Ann Arbor, MI.

Mitnick, B. M. (2015). Agency theory. Wiley Encyclopedia of Management.

Morck, R., \& Yeung, B. (2003). Agency problems in large family business groups. Entrepreneurship Theory and Practice, 27(4), 367-382. https://doi.org/10.1111/1540-8520.t01-1-00015 
Mulyani, E., Singh, H., \& Mishra, S. (2016). Dividends, leverage, and family ownership in the emerging Indonesian market. Journal of International Financial Markets, Institutions and Money, 43(1), 16-29. https://doi.org/10.1016/j.intfin.2016.03.004

Pandey, I. M. (2003). Corporate dividend policy and behaviour: The Malaysian evidence. Asian Academy of Management Journal, 8(1), 17-32.

Park, K., \& Jang, S. (2013). Capital structure, free cash flow, diversification and firm performance: A holistic analysis. International Journal of Hospitality Management, 33(1), 51-63. http://doi.org/10.1016/j.ijhm.2013.01.007

Petersen, M. A. (2009). Estimating standard errors in finance panel data sets: Comparing approaches. The Review of Financial Studies, 22(1), 435-480. https://doi.org/10.1093/rfs/hhn053

Pindado, J., Requejo, I., \& Torre, C. D. (2012). Do family firms use dividend policy as a governance mechanism? Evidence from the Euro Zone. Corporate Governance: An International Review, 20(5), 413-431. https://doi.org/10.1111/j.1467-8683.2012.00921.x

Rajan, R. G., \& Zingales, L. (2003). The great reversals: The politics of financial development in the twentieth century. Journal of Financial Economics, 69(1), 5-50. https://doi.org/10.1016/S0304-405X(03)00125-9

Ramli, N. M. (2010). Ownership structure and dividend policy: Evidence from Malaysian companies, International Review of Business Research Papers, 6(1), 170-180.

Rozeff, M. (1982). Growth, beta and agency costs as determinants of dividend pay-out ratios. Journal of Financial Research, 5(3), 249-259. https://doi.org/10.1111/j.1475-6803.1982.tb00299.x

Saxena, A. K. (1999). Determinants of dividend pay-out policy: Regulated versus unregulated firms. Journal of Applied Topics in Business and Economics, 34(1), 42-52.

Schmid, T., Ampenberger. M., Kaserer, C., \& Achleitner. A. K. (2010). Controlling shareholders and pay-out policy: Do founding families have a special 'taste for dividends'? CEFS working paper series. http://hdl.handle.net/10419/37331

Securities Commission (2017). Malaysian code on corporate governance 2012 (MCCG 2012). Available at http://www.sc.com.my/eng/html/cg/cg2012.pdf [2017, November 10].

Setia-Atmaja, L., Tanewski, G. A., \& Skully, M. (2009). The role of dividends, debt and board structure in the governance of family controlled firms. Journal of Business Finance and Accounting, 36(7-8), 863-898. https://doi.org/10.1111/j.1468-5957.2009.02151.x

Shleifer, A., \& Vishny, R. W. (1986). Large shareholders and corporate control. The Journal of Political Economy, 94(3), 461-488. http://doi.org/10.1086/261385

The Economist. (2015). To have and to hold. pp. 1-14.

Van-den-Berghe, L. A. A., \& Carchon, S. (2001). Corporate Governance practices in Flemish family businesses. Unpublished Working Paper.

Weisskopf, J. P. (2010). Do not wake sleeping dogs: Payout Policies in Founding Family Firms. Working Paper.

Wiwattanakantang, Y. (2001). Controlling shareholders and corporate value: Evidence from Thailand. Pacific-Basin Finance Journal, 9(4), 323-362. https://doi.org/10.1016/S0927-538X(01)00022-1

Yap, J. (2012). Malaysia among the highest in dividend. The Borneo Post Journal, 9(3), 145-150.

Young, M. N., Peng, M. W., Ahlstrom, D., Bruton, G. D., \& Jiang, Y. (2008). Corporate governance in emerging economies: A review of the principal-principal perspective: Review paper. Journal of Management Studies, 45(1), 196-220. https://doi.org/10.1111/j.1467-6486.2007.00752.x

\section{Copyrights}

Copyright for this article is retained by the author(s), with first publication rights granted to the journal.

This is an open-access article distributed under the terms and conditions of the Creative Commons Attribution license (http://creativecommons.org/licenses/by/4.0/). 